2010-10

\title{
A review of bast fibres and their composites. Part 2 - Composites
}

Summerscales, John

http://hdl.handle.net/10026.1/9927

10.1016/j.compositesa.2010.05.020

Composites Part A: Applied Science and Manufacturing

ELSEVIER SCI LTD

All content in PEARL is protected by copyright law. Author manuscripts are made available in accordance with publisher policies. Please cite only the published version using the details provided on the item record or document. In the absence of an open licence (e.g. Creative Commons), permissions for further reuse of content should be sought from the publisher or author. 
Final manuscript of a paper published in Composites Part A:

Applied Science and Manufacturing 41,(10) 1336-1344 , DOI: 10.1016/..compositesa.2010.05.020

\section{A Review of Bast Fibres and their Composites. Part 2 - composites John Summerscales ${ }^{\mathrm{a}, \mathrm{c}}$, Nilmini Dissanayake ${ }^{\mathrm{a}}$, Amandeep Virk ${ }^{\mathrm{a}}$ and Wayne Hall ${ }^{\mathrm{b}}$}

(a) Advanced Composites Manufacturing Centre, School of Marine Science and Engineering

Reynolds Building, University of Plymouth, Plymouth, Devon PL4 8AA, United Kingdom.

(b) Griffith School of Engineering, Gold Coast campus, Griffith University,

Queensland 4222, Australia

(c) corresponding author. E-mail: jsummerscales@plymouth.ac.uk

\section{Abstract:}

Bast fibres are defined as those obtained from the outer cell layers of the stems of various plants. The fibres find use in textile applications and are increasingly being considered as reinforcements for polymer matrix composites as they are perceived to be "sustainable". The fibres are composed primarily of cellulose which potentially has a Young's modulus of $\sim 140 \mathrm{GPa}$ (being a value comparable with man-made aramid [Kevlar/Twaron] fibres). The plants which are currently attracting most interest are flax and hemp (in temperate climates) or jute and kenaf (in tropical climates). Part 2 of this review will consider the prediction of the properties of natural fibre reinforced composites, manufacturing techniques and composite materials characterisation using microscopy, mechanical, chemical and thermal techniques. The review will close with a brief overview of the potential applications and the environmental considerations which might expedite or constrain the adoption of these composites.

\section{Prediction of Mechanical Properties}

The elastic modulus of a composite material can normally be predicted using the standard rule of mixtures (Equation 1) [1]:

$$
E_{c}=\eta_{l} \eta_{o} V_{f} E_{f}+V_{m} E_{m}
$$

Equation 1

where $\eta_{l}$ is the fibre length distribution factor, $\eta_{o}$ is the fibre orientation distribution factor, $E_{f}$ is the elastic modulus of the fibre (Vincent [2] has estimated a modulus of up to $140 \mathrm{GPa}$ for cellulose fibres), $E_{m}$ is the elastic modulus of the matrix, $V_{f}$ is the fibre volume fraction and $V_{m}$ is the matrix volume fraction (assuming $V_{f}+V_{m}=1$, i.e. no voids or other inclusions). At this stage in the review, we have neglected the void which occurs within the fibre on the expectation that it will not influence the above. There is an interdependency within $\mathrm{V}_{\mathrm{f}} \mathrm{E}_{\mathrm{f}}$ given that the fibre cross-section and modulus could be calculated on the gross area or the net area after taking the lumen into consideration. The previous assumption would then become $V_{f}+V_{m}+V_{v}+V_{l}=1$, where $V_{v}$ is the volume fraction of voids in the matrix and at the interface and $\mathrm{V}_{\mathrm{l}}$ is the volume fraction of lumen as a proportion of the whole composite.

\section{Effect of voids}

Madsen et al [3] have developed a model to predict the volumetric composition (volume fractions of fibres, matrix and porosity) and density of composites as a function of the fibre weight fraction. The model is particularly aimed at plant fibre composites, but is also valid for all other composites. The porosity is initially divided into three parts associated with the fibre, the interface and the matrix. Madsen et al [4] have presented a modified rule of mixtures to include the influence of porosity on the composite stiffness. The model (Equation 2) integrates the volumetric composition of the composites with their mechanical properties.

$$
E_{c}=\left(\eta_{l} \eta_{o} V_{f} E_{f}+V_{m} E_{m}\right)\left(1-V_{p}\right)^{n}
$$

Equation 2

where $V_{p}$ is the volume fraction of porosity derived from weight fractions of the other components and $n$ is a porosity efficiency exponent quantifying the effect of porosity which gives rise to stress concentrations in the composites. When $n=0$, the porosity in the composite has no effect beyond lowering the load bearing volume. The model was validated with experimental data for volumetric composition and stiffness for several (plant) fibre composites.

\section{Effect of fibre diameter}

Lamy and Baley [5] conducted tensile tests on flax fibres of different diameters, $d_{i}$, and found that the Young's modulus for each class, $E_{i}$, decreased with increasing fibre diameter, where $i$ is the class number (Table 1). They have proposed Equation 3 for the longitudinal elastic modulus, $E_{L}$, of a unidirectional flax-fibre composite material:

$$
E_{L}=V_{f} \sum_{i=1}^{n} \frac{n_{i} d_{i}^{2}}{\sum_{i=1}^{n} n_{i} d_{i}^{2}} E_{i}+V_{m} E_{m}
$$

Equation 3

where $n_{i}$ is the number of samples (in classes of width $2.5 \mu \mathrm{m}$ for diameters between 5-35 $\mu \mathrm{m}$ ) and $E_{i}$ is the Young's modulus of fibres in the range $i$. For the sample of fibres tested, $K_{i}$ is the contribution of $n_{i}$ fibres of mean diameter $d_{i}$ to an effective elastic modulus $E_{f}$ of $59 \mathrm{GPa}$ which in turn gave a reasonable prediction of the composite modulus.

Table 1: Dependence of properties of flax fibre on fibre diameter (Tables 1/2 of Lamy and Baley [5]) 
Final manuscript of a paper published in Composites Part A:

Applied Science and Manufacturing 41,(10) 1336-1344, DOI: 10.1016/j.compositesa.2010.05.020

The dependence of the modulus of the composite, calculated using Equation 3, against fibre volume fraction correlated well with the experimental results. It was noted that selection of fibre diameters could be a route to improvement of the elastic properties of flax fibre reinforced epoxy resin composite materials. Baley [6] reported a decrease in the Young's modulus with increasing fibre diameter for flax fibres (Fig.1a). Bodros and Baley [7] found that the Young's modulus and the stress at break of nettle fibres decreased when the fibre diameter increased (Fig. 1b).

\section{Figure 1: Young's modulus as a function of fibre diameter for (left) flax and (right) nettle (reproduced from data, published in [5] and [7] respectively, kindly provided by $\mathrm{C}$ Baley with permission for use here)}

The authors of this review propose a modification of the rule of mixtures through the use of a fibre diameter distribution factor, $\eta_{d}$, (with values in the range 0-1) to produce Equation 4. This fibre diameter distribution factor will be related to the probability density function for the fibre diameter, which could be obtained from a comprehensive study of the chosen fibre and may well correlate to the factor given in Equation 3. Derivation of that parameter is beyond the scope of this review.

$$
E_{c}=\eta_{d} \eta_{l} \eta_{o} V_{f} E_{f}+V_{m} E_{m}
$$

Equation 4

This equation might be modified to incorporate the porosity efficiency exponent above.

\section{Composites Processing}

The techniques for the manufacture of fibre-reinforced polymer matrix composites have been reviewed by Åström, Gutowski, Davé and Loos and Campbell [8-11], albeit that their emphasis is very much on synthetic fibres and thermosetting resins. Thermoset processes have been considered in greater detail:

- $\quad$ vacuum bagging, including autoclave cure [12-14]

- Compression moulding [no key text]

- $\quad$ Liquid Moulding Technologies (LMT) or Liquid Composite Moulding (LCM), including Resin Transfer Moulding (RTM) [15-21].

- $\quad$ Resin Infusion under Flexible Tooling (RIFT) [22-25].

- $\quad$ Filament winding [26].

- Pultrusion [27, 28].

The latter two processes will require that the natural fibres be spun to form a continuous yarn

For thermoplastic matrix composites, there are additional processes including extrusion (for constant cross section) and injection moulding. LMT and RIFT are possible only with a few thermoplastic systems supplied as low viscosity monomers and these are normally polymerised in-process. Vacuum bagging, filament winding and pultrusion are also possible.

Glass fibres are generally assumed to be homogeneous and isotropic, although Stockhorst and Brueker [29] have shown a very small preferred orientation through stress optical investigation. Bast fibres are generally heterogeneous and anisotropic and thus closer to the structure of carbon and especially aramid fibres. Pinzelli [30] reviewed the state-ofthe-art in cutting and machining of composite materials based on aramid fibre reinforcements, and recommended that a band-saw with a fine tooth blade (14-22 raker-set or straight-set teeth/inch [ 5-9 teeth/cm]) operating at high surface speeds with the running blade teeth pointing upwards (reverse) should minimise the production of fuzz and keep the teeth from snagging fibres. Cullen [31] machined flax/jute epoxy composites using a band saw with 7 teeth/cm (18 teeth/inch) running in either the forward or the reverse direction. The reverse configuration cut the fibres much more cleanly than when running with the teeth facing forwards. The Pinzelli report considers other aspects of machining aramid composites which may be relevant to natural fibre composites.

\section{Materials characterisation}

The determination of the parameters required for the rule-of-mixtures can be achieved in a variety of ways, including the Grafil [32], Composite Research Advisory Group (CRAG) [33] or (inter-)national standard procedures. Optical or electron microscopical techniques with image analysis [34-36] may be used to determine $\eta_{d}, \eta_{l}, \eta_{o}$ and volume fractions of the components (fibre, matrix and voids including lumen) in the composite materials. For natural fibres in a resin matrix, it will normally be necessary to enhance the contrast between the components (by e.g. polarising filters, fluorescence or staining techniques - Dubot [37] used methylene-blue as a stain for linseed fibres). Grafil Test Method 102.13 uses microscopy with an image splitting eyepiece to determine individual fibre diameters.

Optical coherence microscopy (OCM, also known as optical coherence tomography (OCT)) is a novel imaging technique which permits the acquisition of tomographic images with high resolution ( $15 \mu \mathrm{m}$ in three dimensions) and a high dynamic range $(>100 \mathrm{~dB})$. . Reeves et al [38] have applied OCM to visualise the cellular and subcellular structures within intact Arabidopsis plants (including leaves, flowers, ovules and seeds). 
Final manuscript of a paper published in Composites Part $A$ :

Applied Science and Manufacturing 41,(10) 1336-1344, DOI: 10.1016/j.compositesa.2010.05.020

Thumm [39] has used confocal microscopy to determine the interfacial behaviour and (non-) interactions in plant fibre composites. Labelled dyes were added to the polymer matrix to enhance the fluorescence. The extent of interaction was indicated by line profiles of the fluorescence for each component.

The determination of volume fraction of the composite is problematic and will be dependent on the moisture level and any consequent changes in the dimensions and weight of hygroscopic natural fibres (and will be a function of changes in the ambient relative humidity and of diffusion rates). A graph of fibre density against moisture content would provide useful data. Subject to the constraints above, the fibre volume fraction of composite materials may be obtained by appropriate manipulation of data from the following methods [32, 33]:

- tow counting for unidirectional composites in an open-ended mould (Grafil Test Method 302.24) or from fabric areal weight in a moulding of known thickness (CRAG method 1000-2).

- direct weighing (Grafil Test Method 302.13) when a closed mould is used and no fibre is lost in the moulding flash. The mass fraction is then the mass of fibre divided by the mass of the composite after fabrication. Accurate values of the density of the components are necessary to convert the mass fraction to a fibre volume fraction.

- density gradient column (Grafil Test Method 301.12) which is based on observing the level to which the test specimen sinks in a column of liquid when the density of liquid changes uniformly with height. The absorption of liquid by the test specimen may complicate the analysis for this technique when natural fibres are under test.

- Archimedes principle (Grafil Test Method 301.21. CRAG methods 800/1000-1) using weight measurements in air and in water. The absorption of liquid by the test specimen may complicate the analysis for this technique when natural fibres are under test.

- resin burn-off (CRAG method $1000-3 \mathrm{c}$ ) in an oven at $580-600^{\circ} \mathrm{C}$. This method is inappropriate for natural fibre composites as both components of the composite will burn. It may be possible to use Thermo Gravimetric Analysis (TGA, possibly in combination with both normal and inert atmospheres) to determine the volume fraction if the two components have clearly differentiated decomposition temperatures. The technique has been used by Sharma et al [40-42] to characterise the components of flax fibres.

- chemical digestion using sulphuric acid and hydrogen peroxide (Grafil Test Method 302.56. CRAG method 1000-3a) or nitric acid (CRAG method 1000-3b). It may be necessary to select different chemicals for natural fibre composites. Green [43] has proposed the use of a microwave acid digestion bomb for the determination of fibre volume fraction of carbon-epoxy composites. This may be suitable for natural fibre composites. The "bomb" is a sealed chemically-inert vessel in which microwave heating can be used for rapid sample dissolution. These bombs can be placed directly in a microwave oven for specific, high speed heating to drastically reduce the time required to dissolve or digest an analytical sample [44].

An even more challenging task is the determination of porosity levels. For high performance composites, voids are assumed to be randomly distributed and to occur only in the matrix. The resolution of void volume fraction is normally taken to be no better than $\pm 0.5 \%$. However, with plant fibre reinforcements, porosity may be found in any of the components of the composite. The Grafil test method 303.14 [32] (intended for hydrophobic carbon fibres) has a Standard Density Method for Void Content determined from the mass of fibre in a mass of composites when the density of the fibre and the resin are known and the density of the composite is determined experimentally. CRAG test method 1001 [33] (again intended for man-made fibre composites) describes an ultrasonic scanning technique and requires appropriate calibration blocks.

Typical mechanical properties for natural fibre reinforced polymer matrix composites are given in Table 2 and plotted against predictions using the rule of mixtures (Equation 1) in Figure 2.

Table 2: Typical properties of natural fibre reinforced polymer matrix composites (nb: specific results* reported here are for the composite with highest elastic modulus reported in each paper)

\section{Figure 2: Variation of Young's modulus with fibre orientation plotted against fibre volume fraction (a constant fibre modulus of $50 \mathrm{GPa}$ has been assumed for the trendlines)}

\section{Effect of water}

A potential problem with natural fibre reinforced polymer matrix composites is the hydrophilic nature of the cellulose fibres and hence the moisture sensitivity of the resulting composites. Khalil et al [52] have studied the acetylation of plant fibres in the context of improvement of the mechanical properties of composites. Bast fibres from jute and flax were considered (along with coconut fibre (coir), oil palm empty fruit bunch (EFB) and oil palm frond (OPF)). The two bast fibres were found to be the least reactive of the five fibres studied.

Costa and D'Almeida [53] studied the effect of water absorption on the flexural properties of jute or sisal fibre reinforced polyester or epoxy matrix composites. The diffusion behaviour in both composites could be described by the Fickian model. Of the four systems studied, the jute-epoxy composites showed the best mechanical properties and still had superior performance after exposure of the composites to distilled water (Figure 3). This behaviour was attributed to a better fibre-matrix interface and better moisture resistance of jute fibres. 
Final manuscript of a paper published in Composites Part A:

Applied Science and Manufacturing 41,(10) 1336-1344, DOI: 10.1016/j.compositesa.2010.05.020

\begin{abstract}
Figure 3: The deterioration of flexural modulus and strength for jute fibre composites

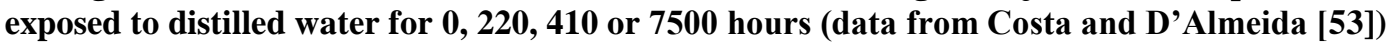

\title{
Markets and Current Applications
}

The world market for composites was 7 million tonnes in 2000, and projected to reach 10 million tonnes in 2010 [54]:

- the North American market accounts for nearly half of world-wide composites (3.4 million tonnes - 47\%),

- $\quad$ Europe follows at 2 million tonnes $-28 \%$,

- Asia is the third major market at 1.6 million tonnes $-23 \%$.

The principal European producers are Germany, Italy, France, UK and Spain. Thermoset composites account for roughly $70 \%$ of the composites processing industry in Europe.

There is a wide range of user industries for composites in all the international markets, including mechanical structures, chemical plant and electrical insulators. It should be noted that although automotive and aerospace applications account for over half the value, the volume consumption is only $26 \%$. Whilst composites for these industries (and medical and sports applications) are often based on high cost carbon and aramid fibres, there is a mass market for low cost composites - the GRP industry, based predominantly on glass fibre reinforcement and polyester resins.

By Western standards, the Indian composites industry is relatively small at 17000 tonnes in 2001 compared to France at 295000 tonnes [55]. After a period of exceptional growth up to 1999, the Indian industry has failed to live up its growth potential in recent years, and is relatively stagnant. The industry suffers from fragmentation (over 1,700 processors), weak demand from client sectors, under-utilisation of capacity, and quality problems.

European production of natural fibre amounted to 59000-69000 tonnes of flax and 25000-30000 tonnes of hemp in 1999/2000 [56]. During the same year, world production of jute and kenaf was 2570000 tonnes, concentrated in two main producer countries, India and Bangladesh. Production of jute and kenaf declined by $49 \%$ and $19 \%$ respectively from a peak of 3860000 tonnes in 1997/8 [57].

The use of natural fibres as reinforcement for thermoplastic components is a relatively new phenomenon, dating back only to about 1995. The market has developed from pioneering work in the German automotive industry [58]. In this market, jute is in competition with the indigenous European fibres, flax and hemp, and despite being used at the outset, has consistently fluctuated in relative market share. Figure 4 shows the total consumption of natural fibres increasing to 17 thousand tonnes in 2002 [59]: estimated as flax at 9,000 tonnes and hemp at about 2,200 tonnes with the balance of 6,000 tonnes split between jute, kenaf and sisal.

\section{Figure 4: Use of natural fibres in the German automotive industry 1996 - 2002 (tonnes) (after Kaup et al, 2003 [58]).}

The Status Report [59] scaled down the forecast of future consumption of natural fibres. Previous optimistic estimates of up to 35000 tonnes/year were reduced to just over 25000 tonnes in 2005. An earlier report [60] indicated that Germany alone was responsible for over two-thirds of the European production of natural fibre composites, and estimated the market size to be somewhat larger than the Status study. In Germany, the natural fibre composites market has created a dedicated infrastructure of secondary suppliers (mainly non-woven producers) and is still growing strongly. The phased withdrawal of EU Common Agricultural Policy (CAP) subsidy on flax and hemp fibre crops may retard the growth of this new industry.

Ellison and McNaught [60] have identified established commercial uses in:

- automotive interior components (Germany 70\%). Natural fibre panels are now in common use as door and boot liners and parcel shelves. Every Mercedes and BMW model now features such components, and the technology has been taken into the Fiat group, Ford and the volume French marques by Tier One suppliers. Current use amounts to about $10 \mathrm{~kg}$ per car, with a potential for double this consumption.

- domestic insulation (Germany 30\%) - tow or sliver bound lightly with polymers.

Established benefits for the automotive industry include good mechanical properties, fewer occupational health issues in handling and lack of splintering in accidents. A review of relevant properties demonstrated the potential for competition with GRP (Glass Reinforced Plastics) [59]. However, the principal drivers are the potential for weight reduction (10-30\%) and the consequent cost advantage of natural fibre composites.

Further, they established that two processes were dominant:

- Compression moulding: Thermoplastic mouldings usually comprise natural fibre/polypropylene blended needlefelt substrates. Thermosets consist of $100 \%$ natural fibre needle-felts impregnated with resin by processes such as RTM and S-RIM. The market is dominated by fibre carded sliver or tow chopped to a staple length of $80-90 \mathrm{~mm}$. 
Final manuscript of a paper published in Composites Part A:

Applied Science and Manufacturing 41,(10) 1336-1344, DOI: 10.1016/j.compositesa.2010.05.020

- Co-extruded granulate for injection moulding is now under development on several fronts (Daimler Benz ASG in Germany, Collins \& Aikmann Automotive Systems AB (formerly Perstorp) in Sweden, ATO-DLO Agrotechnological Research Institute in the Netherlands), and already has an estimated $4.7 \%$ share of automotive processing technology in Germany [59]. Short chopped sliver of 4-6 $\mathrm{mm}$ is now being used for co-injection.

Low fibre prices remain an obstacle to investment in the natural fibre supply chain. The Ellison and McNaught study in early 2000 [60] found benchmark prices for jute, flax or hemp to be in the range $€ 0.46-0.61 / \mathrm{kg}$ (converted from DM $0.90-1.20 / \mathrm{kg}$ using the irrevocably fixed conversion rate of $€ 1=1.95583 \mathrm{DM}$ from 1 January 1999 [61]), and three years later (after the introduction of the Euro), wholesale price levels remained in the $€ 0.55-0.62 / \mathrm{kg}$ range. Prices were set at a low level in the mid-1990s and the automotive industry remains a stringent taskmaster.

The major constraints on the application of natural fibres as reinforcements include

- batch-to-batch inconsistency and other fibre quality considerations.

- $\quad$ performance limitations, notably tensile strength and impact strength.

- $\quad$ susceptibility to moisture absorption.

- odour and fogging.

\section{Disposal of natural fibre composites}

Conroy et al [62,63] and Halliwell [64] have reviewed the end-of-life options for composites waste using the waste hierarchy:

- Waste reduction $>$ re-use $>$ recovery $>$ disposal.

Rathje and Murphy [65] have divided recycling into four categories:

- Primary: reprocessing waste to obtain product comparable to the original version,

- Secondary: recovery of waste material with lower performance when compared to virgin materials,

- Tertiary: decomposition of materials to recover monomers, feedstock materials or fuels,

- Quaternary: recovery of the embedded energy in the materials.

An important consideration in the manufacture of any composites is the minimisation of waste associated with the manufacturing process. This waste has the advantage over post-consumer waste that it will normally be well characterised, whereas end-of-life waste is more likely to consist of a mixture of component materials. For thermosetting matrix composites, the only options for re-use or recovery would be in the second-hand spares market or as fillers respectively. For thermoplastic matrix materials, there is the additional option of granulation and reuse in, for example, the extrusion or injection moulding processes. However, this will expose the composite to a further heatform-cool cycle and could impose additional thermal damage on the fibres.

The options for fibre and feedstock recovery for composites in general include:

- incineration [66]: this destroys the resin, but can leave usable carbon or glass fibres albeit with a reduction in the fibre mechanical properties.

- pyrolysis $[67,68]$ : heated to temperatures of typically $400-600^{\circ} \mathrm{C}$ in an oxygen-free atmosphere.

- catalytic transformation [69], acid digestion or solvolytic/solvothermal processes (including hydrolysis and glycolysis).

- $\quad$ sub-, near- and super-critical fluids: this normally includes water (at $300-500^{\circ} \mathrm{C}$ ) or carbon dioxide. PiñeroHernanz et al [70] recycled carbon fibre using a batch-reactor in the temperature range $250-400^{\circ} \mathrm{C}$ with pressures from 4 to $27 \mathrm{MPa}$ and residence times up to 30 minutes. Iwaya et al [71] have depolymerised glassfibre/polyester composites to separate the fibre, filler and polymer using sub-critical diethyleneglycol monomethylether (DGMM) or benzyl alcohol (BZA) in a batch reactor at $190-350{ }^{\circ} \mathrm{C}$ for $1-8$ hours.

However, the cellulosic bast fibres will probably be consumed along with the resin in these processes.

There are two disposal methods especially suited to natural-fibre and bio-based resin composites:

\section{Composting}

A biodegradable material is expected to reach a defined extent of degradation by biological activity under specific environmental conditions within a given time under standard test conditions [72]. Krzan et al [73] have recently reviewed the standards and certification appropriate to environmentally degradable plastics. The EU Directive on Packaging and Packaging Waste (94/62/EC) criteria for biodegradability are set out in BS EN 13432:2000 while the criteria in North America are set out in ASTM D6400-99. The requirements of the standard include:

- biodegradation: over $90 \%$ relative to the standard (cellulose) in 180 days under conditions of controlled composting using respirometric methods (ISO14855),

- disintegration: over $90 \%$ in 3 months (ISO FDIS 16929),

- ecotoxicity: test results for aquatic and terrestrial organisms (Daphnia magna, worm test, germination test) as for reference compost,

- absence of hazardous chemicals (included in a reference list). 
The biodegradation of a polymeric materials under controlled composting conditions can be determined using standard methods including ASTM D 5338 [74] or ISO 14852 [75]. There are essentially two options (a) aerobic: carried out either in open air windrows or in enclosed vessels, or (b) anaerobic: required when animal by-products or catering wastes are included [76]. A demonstration-scale anaerobic digestion (AD) plant is operating at Dufferin (Toronto) solid waste transfer station with a mass balance (based on 100 metric tonnes/day) of $50 \%$ biogas and effluent, $25 \%$ digestate and $25 \%$ residue [77]. The biogas varies due to the batch operation but is typically $110 \mathrm{~m}^{3} /$ tonne with an average of $56 \%$ methane (ranges from $45-73 \%$ ) by volume. Jana et al [78] suggest that the biogas is typically $60-65 \%$ methane, $35 \%$ carbon dioxide and a small amount of other impurities". Greenham and Walsh [79] state that "pure landfill gas" can contain up to $65 \%$ methane, $35 \%$ carbon dioxide and no oxygen. The Global Warming Potential (GWP) for methane is $>20$ times that of $\mathrm{CO}_{2}$ (over a 100 year timescale), so composting should be carried out with the methane collected and burnt to produce energy. This will reduce the requirement for fossil fuels and hence limit the climate change effects.

Organisms that possess cellulase (the enzyme which cleaves sugar from the cellulose molecule) include bacteria, some flagellate and ciliate protozoa, and fungi [80]. Milner et al [81, 82] have reported a new strain of thermophylic bacteria that can break down cellulose waste to produce useful renewable fuels for the transport industry. The Geobacillus family normally synthesise sugars and produce lactic acid as a by-product when they break down biomass in a compost heap. The re-engineered TM242 strain is claimed to produce ethanol more efficiently (yields of 10 to $15 \%$ ) and cheaply than in traditional yeast-based fermentation.

\section{Incineration with energy recovery [83]}

Considerable energy is used in the production of polymers (embodied energy of plastics in general is given as $90 \mathrm{MJ} / \mathrm{kg}$ [84]), but as in many other systems that energy is not lost and can be recovered at a later stage. Halliwell [64] quotes a figure of $36 \mathrm{MJ} / \mathrm{kg}$ as the energy value for ground composite containing man-made fibres. The cellulose in bast fibres will provide additional energy. During recovery of the energy content of the materials, it will be necessary to comply with the Waste Incineration Directive (WID, agreed by the European Parliament and the Council of the European Union on 4 December 2000). The Commission Directive 2000/76/EC aims to "prevent or limit, as far as practicable, negative effects on the environment, in particular pollution by emissions into air, soil, surface and groundwater, and the resulting risks to human health, from the incineration and co-incineration of waste". It sets and seeks to maintain stringent operational conditions and emission limit values for (co-)incineration plants throughout the European Community [85].

\section{Environmental Considerations}

The End-of-Life Vehicle (ELV) Directive was enacted by the European Commission (EC) during 2002 to address pollution resulting from vehicles that have reached the end of their useful life. It aimed to significantly reduce the 8 million tonnes of waste generated each year by the 12 million cars that have reached their end of life. In phase one of the directive, car makers were responsible for the disposal of all new production that would eventually become ELV. In 2007, they became responsible for all the vehicles they had ever produced. The legislation also stipulates that carmakers must re-use or recover $85 \%$ of ELVs by weight. At least $80 \%$ of that weight must be re-used or recycled while up to $5 \%$ can be dealt with through other recovery operations such as incineration. In 2015, this target will rise to $95 \%$ of ELVs by weight, $85 \%$ of which must be re-used or recycled.

The new directives on landfill and ELV, encourage industry to move away from landfill and energy recovery towards mechanical recycling or reuse. Customers (especially in the automotive sector) are increasingly asking the composites industry to accept responsibility for recycling the end-of life waste. In the context of the EC directives, it will be necessary to make a strong case for disposal by incineration or by composting. Composites, based on natural fibre reinforcements, could prove to be more beneficial in the environment than "recyclable" materials but there is a need for quantitative life cycle analysis to clearly demonstrate that this is indeed the case.

Joshi et al [86] reviewed comparative life cycle assessment studies to conclude that natural fibres would be environmentally superior to glass fibre reinforced composites. The key drivers in favour of natural fibres were:

- natural fibre production has lower environmental impacts compared to glass fibre production,

- natural fibre composites have higher fibre content for equivalent performance, reducing the more-polluting polymer content,

- the light-weight natural fibre composites improve fuel efficiency and reduce emissions in the use phase of the component (especially in automotive applications), and

- end-of-life incineration results in recovered energy and carbon credits.

However, the conclusions are tempered by two caveats:

- fertiliser use in natural fibre cultivation results in higher nitrate and phosphate emissions which can lead to increased eutrophication in local water bodies, and

- the environmental superiority of natural fibre composites may be negated if the operating lifetime is significantly reduced compared to the glass fibre composites. 
Reed and Williams [87] have examined the potential for waste biomass (in the form of natural hemp, flax, jute, coir or abaca fibres) to produce activated carbon. After pyrolysis in a fixed bed reactor and steam activation, the yield of activated carbon was $20 \%$ by weight of the original biomass and surface areas were in the range $770-879 \mathrm{~m}^{2} / \mathrm{g}$.

The environmental impact of natural fibres in industrial applications has been reviewed by van Dam and Bos [88]. They include quantitative data and suggest that:

- natural fibre production requires $<10$ percent of the energy used for production of PP fibres (around 90 GJ/tonne).

- the total energy input for jute fibre cultivation (excluding field labour, retting and decortication) was calculated at 3.8-8.0 GJ/tonne when grown by numerous small farmers utilising labour and animal power with limited use of agrochemicals and machinery.

- the energy input from inorganic fertilisers, based on the energy content of the substance and the energy required for production, transport, storage and application is $17 \mathrm{GJ} /$ tonne for potassium $(\mathrm{K}), 26 \mathrm{GJ} /$ tonne for phosphorous $(\mathrm{P})$ and $128 \mathrm{GJ} /$ tonne for nitrogen $(\mathrm{N})$.

- the energy input from pesticides, based on the energy content of the substance and the energy required for production, transport, storage and application is 320-476 GJ/tonne for fungicides, 461-568 GJ/tonne for insecticides and 467-622 GJ/tonne for herbicides.

In an independent analysis, Khan [89] calculated that the total energy consumed, including the embodied energies of fertilisers and pesticides would be $18-20 \mathrm{GJ} /$ tonne of jute fibre.

Dissanayake et al [90-92] have begun to undertake a Quantitative Life Cycle Assessment (QLCA) to compare flax fibres and E-glass fibres as the reinforcement for composites within an ISO 14040 framework. They are considering all eight environmental impact classification factors (EICF) identified by Azapagic [93, 94], ISO 14047 [95] and the European Environment Agency [96] (Table 3). The total energy required [97, 98] using low energy agricultural processes was found to be $54.2 \mathrm{GJ} /$ tonne for flax sliver and $80.5 \mathrm{GJ} /$ tonne for yarn (Table 4). Traditional mouldboard ploughing and bio retting was found to require $118 \mathrm{GJ} /$ tonne for sliver and $146 \mathrm{GJ} /$ tonne for yarn. Fibreglass (insulation) and fibreglass reinforcement mats are reported to have embodied energies of $30 \mathrm{GJ} /$ tonne [99] and 54.7 GJ/tonne [88] respectively! The analysis for the full set of EICF is on-going.

Table 3: A correlation of the eight environmental impact classification factors Table 4: Energy consumption (GJ/tonne of processed fibre) at the various stages of fibre production

\section{SUMMARY}

Part 1 of this review paper has considered the growth, harvesting and fibre separation techniques suitable to yield bast fibre of appropriate quality for use as the reinforcement of polymer-matrix composites. The text then addressed the characterisation of the fibre. Part 2 of this review considered the use of the basic rule-of-mixtures in the context of natural fibre reinforced composites and addressed the characterisation of composite materials using microscopical, mechanical, chemical and thermal techniques. The text closed with a brief overview of some potential applications and the environmental considerations which might expedite or constrain the adoption of these composites. There are a number of factors which could constrain the commercial adoption of these fibres as reinforcements for composites:

- Unlike man-made fibres, the fibre cross section is neither circular nor uniform along the length which leads to increased complexity in the calculation of fibre volume fraction and hence in the prediction of the mechanical properties.

- It may be necessary to determine a fibre diameter distribution factor and how that factor might be incorporated into the rule-of-mixtures.

- The interface between the hydrophilic fibre and a hydrophobic matrix may need special fibre surface treatments or compatibilisers in the matrix.

- The fibres degrade over time at $200^{\circ} \mathrm{C}$ of higher, so the choice of matrix system for the composite is limited.

- Cellulose fibres have similar characteristics to aramid fibres and hence specialised cutting and machining technologies may be needed.

- The "green" claim for natural fibre composites may only be appropriate when best practice is adopted in the growth, separation and processing of the fibres and where the durability of the composite component is comparable to that of glass fibre composites.

\section{ACKNOWLEDGEMENTS}

The authors would like to thank (a) Christophe Baley (Université de Bretagne Sud) for providing the data and permission for its use as Figure 1, (b) Hom Nath Dhakal (University of Portsmouth) and Miggy Singh (University of Plymouth) for their respective comments on draft versions of this paper and (c) the referees who considered an earlier version of this paper and offered some very useful advice. 
Final manuscript of a paper published in Composites Part A:

Applied Science and Manufacturing 41,(10) 1336-1344, DOI: 10.1016/j.compositesa.2010.05.020

\section{REFERENCES}

1 Hull D, An introduction to composite materials, Cambridge: Cambridge University Press; 1981. ISBN 0-52128392-2.

2 JFV Vincent, Structural Biomaterials, Macmillan, London, 1982. ISBN 0-333-26126-7.

3 B Madsen, A Thygesen and H Lilholt, Plant fibre composites - porosity and volumetric interaction, Composites Science and Technology, 2007, 67(7-8), 1584-1600.

4 B Madsen, A Thygesen and H Lilholt, Plant fibre composites - porosity and stiffness, Composites Science and Technology, 2009, 69(7-8), 1057-1069.

5 B Lamy and C Baley, Stiffness prediction of flax fibers-epoxy composite materials, Journal of Materials Science Letters, 1 June 2000, 19(11), 979-980.

6 C Baley, Analysis of the flax fibres tensile behaviour and analysis of the tensile stiffness increase, Composites Part A: Applied Science and Manufacturing, 1 July 2002, 33(7), 939-948.

7 E Bodros and C Baley, Study of the tensile properties of stinging nettle fibres (Urtica dioica), Materials Letters, 15 May 2008, 62(14), 2143-2145.

8 B T Åström, Manufacturing of Polymer Composites, Chapman \& Hall, London, 1997. ISBN 0-412-81960-0.

9 T G Gutowski, Advanced Composites Manufacturing, John Wiley, New York, 1997. ISBN 0-471-15301-x.

10 R S Davé and A C Loos, Processing of Composites, Hanser Publishers, Munich, 1999. ISBN 1-56990-226-7.

11 F Campbell, Manufacturing Processes For Advanced Composites, Elsevier, December 2003. ISBN-13: 978-185617-415-2.

12 PR Ciriscioli and GS Springer, Smart autoclave cure of composites, Technomic Publishing, Lancaster PA, 1990. ISBN 0-87762-802-5.

13 K Noakes, Successful composite techniques: a practical introduction to the use of modern composite materials, second edition, Osprey Automotive, London, 1992. ISBN 1-85532-261-7.

14 S McBeath (foreword by B O'Rourke), Competition car composites : a practical handbook, Haynes, Sparkford Somerset, 2000. ISBN 1-85960-624-5.

15 K van Harten, 'Production by resin transfer moulding', in R A Shenoi and J F Wellicome (editors): Composite Materials in Maritime Structures, Cambridge University Press, Cambridge, 1993, Chapter 4, 86-126.

16 D Abraham and R McIlhagger, A review of liquid injection techniques for the manufacture of aerospace composite structures, Polymers and Polymer Composites, 1996, 4(6), 437-444.

17 K Potter, Resin Transfer Moulding, Chapman \& Hall, London, 1997, ISBN 0-412-72570-3.

18 CD Rudd, AC Long, KN Kendall and CGE Mangin, Liquid Moulding Technologies, Woodhead Publishing, Cambridge, 1997, ISBN 1-85573-242-4.

19 SW Beckwith and CR Hyland, Resin Transfer Molding: a decade of technology advances, SAMPE Journal, November/December 1998, 34(6), 7-19.

20 TM Kruckenberg and R Paton (editors), Resin Transfer Moulding for Aerospace Structures, Kluwer Academic Publishers, Dordrecht NL, 1998, ISBN 0-412-73150-9.

21 R S Parnas, Liquid Composite Moulding, Hanser Gardner Publications, 2000. ISBN 1-569-90287-9.

22 CD Williams, SM Grove and J Summerscales, Resin infusion under flexible tooling (RIFT): a review, Composites Part A: Applied Science and Manufacturing, 1996, A27(7), 517-524.

23 D Cripps, TJ Searle and J Summerscales, Chapter 21: Open Mould Techniques for Thermoset Composites, In R Talreja and J-A Månson (editors): "Comprehensive Composite Materials Encyclopadia, volume 2: Polymer Matrix Composites", Elsevier Science, Oxford, July 2000, pp 737-761. ISBN: 0-08-043725-7.

$24 J$ Summerscales and TJ Searle, Review: Low pressure (vacuum infusion) techniques for moulding large composite structures, Proc IMechE Part L: Journal of Materials: Design and Applications, February 2005, L219(1), 45-58.

25 SW Beckwith, Resin Infusion Technology * Part 1 - Industry highlights $*$ Part 2 - Process definitions and industry variations $*$ Part 3 - A detailed overview of RTM and VIP infusion processing, SAMPE Journal, 2007 , 43(1), 61 and 43(3), 46 and 43(4), 6 \& 66-70.

26 ST Peters, WD Humphrey and RF Foral, Filament winding composite structure fabrication, SAMPE, Covina CA, 1991. ISBN 0-938994-55-7. Second edition, 1999. ISBN 0-938994-81-6.

27 RW Meyer, Handbook of pultrusion technology, Chapman and Hall, London, 1985. ISBN 0-412-00761-4.

28 TF Starr, Pultrusion for engineers, Woodhead, Cambridge, 2000. ISBN 1-85573-425-7.

29 H Stockhorst and R Bruekner, Stress optical investigations of glass fibres with linearly and three dimensionally branched networks, Physics and Chemistry of Glasses, October 1986, 27(5), 204-209.

30 R Pinzelli, Cutting and machining of composite materials based on aramid fibres, DuPont Engineering Fiber Systems, Geneva, 1991 (reprinted from Composites - Plastiques Renforces Fibres de Verre Textile (Paris), July/August 1990, 30(4), pp 17-23 in French with illustrations, pp 23-25 in English, text only. ISSN 0754-0876).

31 RK Cullen, Private conversation, 4 March 2003.

32 Grafil Test Methods (reference 000.05), Courtaulds Limited, Coventry, March 1980.

33 PT Curtis, CRAG Test Methods for the Measurement of the Engineering Properties of Fibre Reinforced Plastics, Royal Aircraft Establishment Technical Report RAE-TR-88-012, February 1988. 
Final manuscript of a paper published in Composites Part A:

Applied Science and Manufacturing 41,(10) 1336-1344, DOI: 10.1016/i.compositesa.2010.05.020

34 FJ Guild and J Summerscales, Microstructural image analysis applied to fibre composite materials: a review, Composites, 1993, 24(5), 383-394.

35 J Summerscales (editor), Microstructural Characterisation of Fibre-Reinforced Composites, Woodhead Publishing, Cambridge, July 1998. ISBN 1-85573-240-8. CRC Press LLC, Boca Raton - Florida, July 1998. ISBN 0-8493-3882-4.

36 AR Clarke and CN Eberhardt, Microscopy Techniques for Materials Science, Woodhead Publishing, Cambridge, July 1998. ISBN 1-85573-587-3. CRC Press LLC, Boca Raton - Florida, July 1998. ISBN 0-8493-1552-2.

37 J-M Dubot (IUT Lannion stage placement student), Characterisation of the mechanical behaviour of linseed fibres in composite materials, University of Plymouth Report, Plymouth, June 2001.

38 A Reeves, RL Parsons, JW Hettinger and JI Medford, In vivo three-dimensional imaging of plants with optical coherence microscopy, Journal of Microscopy, December 2002, 208(3), 177-189.

39 A Thumm, Visualisation of interfacial behaviour of natural fibre composites, Sustainable Composites Network 7th meeting, University of Bath, 11 October 2004.

40 HSS Sharma and K Kernaghan, Thermogravimetric analysis of flax fibres, Thermochim Acta, 29 September 1988, 132, 101-109.

41 HSS Sharma, G Faughey and D McCall, The effect of sample preparation on the differential thermogravimetric analysis of flax fibres, Journal of the Textile Institute, 1996, 87(no 2 part 1), 249-257.

42 GJ Faughey, HSS Sharma and RD McCall, Determining fibre fineness in flax using derivative thermogravimetric analysis, scanning electron microscopy and airflow methods, Journal of Applied Polymer Science, 24 January 2000, 75(4), 508-514.

43 P Green, Fibre volume fraction determination of carbon-epoxy composites using an acid digestion bomb, Journal of Materials Science Letters, 1 October 1991, 10(19), 1162-1164.

44 Microwave Acid Digestion Bombs, http://www.parrinst.com/default.cfm?page_id=210, accessed 19 January 2009 at 17:21.

45 I Van de Weyenberg, J Ivens, A de Coster, B Kino, E Baetens and I Verpoest, Influence of processing and chemical treatment of flax fibres on their composites, Composites Science and Technology, July 2003, 63(9), 1241-1246

46 K Oksman, M Skrifvars and JF Selin, Natural fibres as reinforcement in polylactic acid (PLA) composites, Composite Science and Technology, 2003, 63(9), 1317-1324.

47 E Bodros, I Pillin, N Montrelay and C Baley, Could biopolymers reinforced by randomly scattered flax fibre be used in structural applications?, Composites Science and Technology, March 2007, 67(3-4), 462-470.

$48 \mathrm{~T}$ Yuanjian and DH Isaac, Impact and fatigue behaviour of hemp fibre composites, Composites Science and Technology, December 2007, 67(15-16), 3300-3307.

49 GW Beckermann and KL Pickering, Engineering and evaluation of hemp fibre reinforced polypropylene composites: fibre treatment and matrix modification, Composites Part A: Applied Science and Manufacturing, June 2008, 39(6), 979-988.

50 AC Karmaker and JP Schneider, Mechanical performance of short jute fibre reinforced polypropylene, Journal of Materials Science Letters, January 1996, 15(3), 201-202.

51 A-J Merilä, Stinging nettle fibres as reinforcement in thermoset matrices, MSc Engineering/Materials Technology, Luleå University of Technology, 2000.

52 HPS Abdul Khalil, HD Rozman, MN Ahmad and H Ismail, Acetylated plant-fiber-reinforced polyester composites: a study of mechanical, hygrothermal, and aging characteristics, Polymer-Plastics Technology and Engineering, August 2000, 39(4), 757-781.

53 FHMM Costa and JRM D'Almeida, Effect of Water Absorption on the Mechanical Properties of Sisal and Jute Fiber Composites, Polymer-Plastics Technology and Engineering, November 1999, 38(5), 1081 - 1094.

54 Nodal Consultants, DiGITIP Study for French Govt Service of Manufacturing Industries, 2001.

55 S Sundaram, Indian GRP industry fails to meet expectations, Reinforced Plastics, July/August 2002, 46(7/8), 3439.

56 M Karus, M Kaup and D Lohmeyer, Study on Markets and Prices for Natural Fibres (Germany \& EU) for Fachagentur Nachwachsende Rohstoffe eV, Nova Institute Report FNR-FKZ 99NR163, March 2000.

57 A Liu, World production and potential utilization of jute, kenaf and allied fibres, China Consulting Inc, 2007, accessed 19 January 2009 at 17:23.

58 AK Bledzki and J Gassan, Composites reinforced with cellulose based fibres, Progress in Polymer Science, 1999, 24(2), 221-274.

59 M Kaup, M Karus and S Ortmann, Naturfasereinsatz in Verbundwerkstoffen in der deutschen und österreichischen Automobilindustrie - Status 2002 Analyse und Trends, Nova Institut für Ökologie und Innovation Auswertung der Markterhebung 2002, February 2003. http://www.nova-institut.de/pdf/Markt_NFVerbund.pdf, accessed 19 January 2009 at 17:27.

60 GC Ellison and R McNaught, The use of natural fibres in nonwoven structures for applications as automotive component substrates, Ministry of Agriculture, Fisheries and Food Research and Development report NF 0309, February 2000, accessed 19 January 2009 at 17:28. Alternative source: http://www.ienica.net/usefulreports/auto.pdf accessed 11 September 2009 11:40. 
Final manuscript of a paper published in Composites Part A:

Applied Science and Manufacturing 41,(10) 1336-1344, DOI: 10.1016/j.compositesa.2010.05.020

61 Deutsche Bundesbank Exchange rate statistics 2000, Deutsche Bundesbank, Frankfurt am Main, circa 2000, http://www.bundesbank.de/download/volkswirtschaft/devisenkursstatistik/2000/exchangeratestatistics072000.pdf, accessed 11 September 2009 10:43..

62 A Conroy, S Halliwell, T Reynolds and A Waterman, Recycling fibre reinforced polymers in construction: a guide to best practicable environmental option, BRE Report BR467, 2004. ISBN 1860816894.

63 A Conroy, S Halliwell and T Reynolds (2006), Composite recycling in the construction industry, Composites Part A: Applied Science and Manufacturing, 2006, 37(8), 1216-1222.

64 S Halliwell, End of Life Options for Composite Waste - Recycle, Reuse or Dispose, National Composites Network report, 2006 [NB: it is necessary to register with NCN to access this report online].

65 W Rathje and C Murphy, Rubbish! The archaeology of garbage, Harper-Collins, London, 1992.

66 S Pickering (2010), Chapter 4: Thermal methods for recycling waste composites, in V Goodship (editor): "Management, recycling and reuse of waste composites", Woodhead Publishing, Cambridge, 2010, 65-101.

67 M Blazsó (2010), Chapter 5: Pyrolysis for recycling waste composites, ibid, 2010, 102-121.

68 W. Kaminsky, Chapter 8: Fluidized bed pyrolysis of waste polymer composites for oil and gas recovery, ibid, 2010, 192-214.

69 MA Keane (2010), Chapter 6: Catalytic processing of waste polymer composites. Ibid, 2010, 122-151.

70 RC Piñero-Hernanz, C Dodds, J Hyde, J García-Serna, M Poliakoff, E Lester, M José Cocero, S Kingman, S Pickering and KH Wong, Chemical recycling of carbon fibre reinforced composites in nearcritical and supercritical water', Composites Part A: Applied Science and Manufacturing, 2008, 39 (3), 454-461.

71 T Iwaya, S Tokuno, M Sasaki, M Goto and K Shibata (2008), 'Recycling of fiber reinforced plastics using depolymerization by solvothermal reaction with catalyst', Journal of Materials Science, 43(7), 2452-2456.

72 R Murphy and I Bartle, Biodegradable Polymers and Sustainability: Insights from Life Cycle Assessment, Summary Report presented at the National Non-Food Crops Centre seminar, London, 25 May 2004.

73 A Krzan, S Hemjinda, S Miertus, A Corti and E Chiellini, Standardization and certification in the area of environmentally degradable plastics, Polymer Degradation and Stability, December 2006, 91(12), 2819-2833.

74 ASTM D5338-98(2003): Standard Test Method for Determining Aerobic Biodegradation of Plastic Materials Under Controlled Composting Conditions.

75 ISO 14852 (1999): Determination of the ultimate aerobic biodegradability of plastic materials in an aqueous medium - Method by analysis of evolved carbon dioxide.

76 J Jacobs, The Compositing Association, private communication (e-mail), Monday 26 June 2006 08:45

77 N Goldstein, Source separated organics as feedstock for digesters, BioCycle, August 2005, 46(8), 42.

78 S Jana, NR Chakrabarty and SC Sarkar, Removal of Carbon Dioxide from Biogas for Methane Generation, Journal of Energy in Southern Africa, August 2001, 12(3).

79 L Greenham and P Walsh, Carbon Dioxide Detectors For Health \& Safety Applications, Petro Industry News, December 2004, pp 34-35.

80 J Scott Turner, The Extended Organism: The Physiology of Animal-built Structures, Harvard University Press, September 2002. ISBN 0-674-00985-1.

81 P Milner, SM Martin, KL Eley, R Cripps, E Firth, C Mercier, J Robinson and T Atkinson, Development of a second generation bioethanol process using TM242 - a thermophilic bacillus,

Autumn Meeting, Society for General Microbiology, Trinity College Dublin, 08-11 September 2008, abstracts book page 23 .

82 Compost heap bacteria could help produce renewable fuel, BioTech International, September 2008, $20(4), 26$.

83 P Lettieri, L Yassin and SJR Simons, Chapter 7: Advanced thermal treatment of composite wastes for energy recovery, in V Goodship (editor): "Management, recycling and reuse of waste composites", Woodhead Publishing, Cambridge, 2010, 152-191.

84 B Lawson, Building materials, energy and the environment: Towards ecologically sustainable development, RAIA, Canberra, 1996 as echoed in Technical manual: design for lifestyle and the future,

http://www.greenhouse.gov.au/yourhome/technical/fs31.htm accessed 16 December 2006 at 15:51.

85 DEFRA, Environmental Permitting Guidance - The Directive on the Incineration of Waste, Department for Environment, Food and Rural Affairs, London, 2008, accessible from

http://www.defra.gov.uk/environment/epp/documents/wid-guidance.pdf, accessed 21 August 2008 at 12:18 (NB: includes the full text of the Waste Incineration Directive at Annex 2).

86 SV Joshi, LT Drzal, AK Mohanty and S Arora, Are natural fiber composites environmentally superior to glass fiber reinforced composites?, Composites Part A: Applied Science and Manufacturing, 2004, 35(3), 371-376.

87 AR Reed and PT Williams, Thermal processing of biomass natural fibre wastes by pyrolysis, International Journal of Energy Research, 2004, 28(2), 131-145.

88 JEG van Dam and HL Bos, Consultation on natural fibres: the environmental impact of hard fibres and jute in non-textile industrial applications, ESC-Fibres Consultation no 04/4, Rome, 15-16 December 2004.

89 MA Khan, Life Cycle Assessment of natural vs man-made fibers as reinforcement for composites, MSc dissertation, University of Plymouth, 2007. 
Final manuscript of a paper published in Composites Part A:

Applied Science and Manufacturing 41,(10) 1336-1344, DOI: 10.1016/i.compositesa.2010.05.020

90 NPJ Dissanayake, J Summerscales, SM Grove and MM Singh, Comparative life cycle assessment for natural vs glass fibres as reinforcement for composites, Conference: Sustainable Materials, Polymers \& Composites,

Coventry, 11 September 2007.

91 NPJ Dissanayake, J Summerscales, SM Grove and MM Singh, Comparative life cycle assessment for natural vs glass fibres as reinforcement for composites, Composites Innovation 2007 - improved sustainability and environmental performance, Barcelona, 4-5 October 2007.

92 NDissanayake, J Summerscales, SM Grove, MM Singh, Infusion of natural vs. synthetic fibre composites with similar reinforcement architecture in the context of a LCA, The 9th International Conference on Flow Processes in Composite Materials (FPCM-9), Montréal, 8-10 July 2008. CD-ROM/pdf/z_poster/19.pdf. Book of abstracts page 124 .

93 A Azapagic, A Emsley and I Hamerton, Polymers, the Environment and Sustainable Development, John Wiley \& Sons, March 2003, ISBN 0-471-87741-7.

94 A Azapagic, S Perdan and R Clift (editors), Sustainable Development in Practice - Case Studies for Engineers and Scientists, John Wiley \& Sons, May 2004. ISBN 0-470-85609-2.

95 Environmental Management - Life Cycle Impact Assessment - Examples of Application of ISO14042, International Standard PD ISO/TR 14047:2003(E), 11 December 2003. ISBN 0-580-43112-6.

96 P Kaźmierczyk (editor), Sustainable use and management of natural resources, EEA Report No 9/2005. ISBN 92-9167-770-1. ISSN 1725-9177.

97 NPJ Dissanayake, J Summerscales, SM Grove and MM Singh, Energy use in the production of flax fibre for the reinforcement of composites, Journal of Natural Fibres, 2009, 6(4), 331-346.

98 NPJ Dissanayake, J Summerscales, SM Grove, and MM Singh Life Cycle Impact Assessment of Flax Fibre for the Reinforcement of Composites, Journal of Bio-based Materials and Bio-Energy, 2009, 3(3), 245-248.

99 Table of Embodied Energy Coefficients, Centre for Building Performance Research (NZ), http://www.vuw.ac.nz/cbpr/documents/pdfs/ee-coefficients.pdf, accessed 19 January 2009 at 17:31.

\begin{tabular}{|c|c|c|c|c|c|c|c|c|c|c|c|c|}
\hline \multicolumn{13}{|c|}{$\begin{array}{c}\text { Table 1: Dependence of properties of flax fibre on fibre diameter } \\
\text { (Tables 1/2 of Lamy and Baley [5]) }\end{array}$} \\
\hline Class i & 1 & 2 & 3 & 4 & 5 & 6 & 7 & 8 & 9 & 10 & 11 & 12 \\
\hline $\mathbf{n}_{\mathbf{i}}$ & 6 & 44 & 84 & 136 & 170 & 143 & 121 & 83 & 45 & 25 & 7 & 5 \\
\hline $\mathbf{d}_{\mathbf{i}}(\boldsymbol{\mu m})$ & 6.8 & 8.8 & 11.2 & 13.9 & 16.2 & 18.8 & 21.2 & 23.6 & 26.2 & 28.6 & 32.1 & 34.5 \\
\hline $\mathbf{E}_{\mathbf{i}}(\mathbf{G P a})$ & 79 & 76 & 72 & 69 & 65 & 62 & 58 & 55 & 51 & 47 & 43 & 39 \\
\hline $\begin{array}{r}\mathbf{K}_{\mathbf{i}} \\
(\mathbf{M P a})\end{array}$ & 73 & 860 & 2530 & 5990 & 9670 & 10350 & 10520 & 8400 & 5230 & 3230 & 1020 & 770 \\
\hline
\end{tabular}

Table 2: Typical properties of natural fibre reinforced polymer matrix composites

(nb: specific results* reported here are for the composite with highest elastic modulus reported in each paper)

\begin{tabular}{|c|c|c|c|c|c|c|c|c|}
\hline Fibre & Matrix & Configuration & $\%$ fibre & E (GPa) & $\sigma^{\prime}(\mathrm{MPa})$ & $\varepsilon^{\prime}(\%)$ & Ref & $\begin{array}{l}\text { Source (NB: this column is to ensure } \\
\text { reference numbers are correct - it } \\
\text { should not be published) }\end{array}$ \\
\hline Flax & Epoxy & unidirectional & 40 & 28 & 133 & $\mathrm{n} / \mathrm{a}$ & 45 & Van der Wegenberg et al (2003) \\
\hline Flax & PLLA & aligned roving & $40 \mathrm{v} / \mathrm{o}$ & $7.3 \pm 0.5$ & $44.1 \pm 7.2$ & $0.9 \pm 0.2$ & $46 *$ & Oksman et al (2003)* \\
\hline Flax & PLLA & random mat & $30 \mathrm{v} / \mathrm{o}$ & 9.5 & 99 & 1.5 & $47 *$ & Bodros et al (2007)* \\
\hline Hemp & UP resin & mat & 44 w/o & $6.2 \pm 0.6$ & $53.0 \pm 6.0$ & $1.39 \pm 0.26$ & 48 & Yuanjian \& Isaac (2007) \\
\hline Hemp & $\mathrm{PP}$ & injection moulded & $40 \mathrm{w} / \mathrm{o}$ & 5.3 & 50.5 & $\mathrm{n} / \mathrm{a}$ & 49 & Beckerman \& Pickering (2008) \\
\hline Jute & $\mathrm{PP}$ & injection moulded & $50 \mathrm{w} / \mathrm{o}$ & $5.5 \pm 0.3$ & $32.0 \pm 0.5$ & $\mathrm{n} / \mathrm{a}$ & 50 & Karmaker \& Schneider (1996) \\
\hline Jute & PP/MAPP & injection moulded & $50 \mathrm{w} / \mathrm{o}$ & $5.4 \pm 0.4$ & $57.9 \pm 0.4$ & $\mathrm{n} / \mathrm{a}$ & 50 & Karmaker \& Schneider (1996) \\
\hline Nettle & Epoxy & unidirectional & $24 \mathrm{v} / \mathrm{o}$ & 9 & 91 & $\mathrm{n} / \mathrm{a}$ & 51 & Merilä (2000) \\
\hline Nettle & Phenolic & unidirectional & $23 \mathrm{v} / \mathrm{o}$ & 5 & 13 & $\mathrm{n} / \mathrm{a}$ & 51 & Merilä (2000) \\
\hline
\end{tabular}


Final manuscript of a paper published in Composites Part A:

Applied Science and Manufacturing 41,(10) 1336-1344, DOI: 10.1016/j.compositesa.2010.05.020

Table 3: A correlation of the eight environmental impact classification factors

\begin{tabular}{|l|l|l|}
\hline Azapagic et al [69, 70] & ISO/TR 14047:2003(E) [71] & European Environment Agency [72] \\
\hline Acidification Potential (AP) & Acidification & Ecotoxicity \\
\hline Aquatic Toxicity Potential (ATP) & Ecotoxicity & Eutrophication \\
\hline Eutrophication Potential (EP) & Eutrophication/Nitrification & Climate change and global warming \\
\hline Global Warming Potential (GWP) & Climate change & Human toxicity \\
\hline Human Toxicity Potential (HTP) & Human toxicity & Stratospheric ozone depletion \\
\hline Non-Renewable/Abiotic Resource Depletion (NRADP) & Depletion of abiotic/biotic resources & Photochemical ozone formation (summer smog) \\
\hline Ozone Depletion Potential (ODP) & Stratospheric ozone depletion & Photo-oxidant formation \\
\hline
\end{tabular}

\begin{tabular}{|lcccccc|}
\hline \multicolumn{7}{|c}{ Table 4: Energy consumption (GJ/tonne of processed fibre) at the various stages of fibre production } \\
\hline \multicolumn{1}{|c}{ Sliver } & Cultivation & Agrochemicals & Retting & Textile processes & TOTAL \\
No till + water retting & 4.9 & 37.5 & 0.6 & 11.2 & $\mathbf{5 4 . 2}$ \\
Conservation tillage + stand/dew retting & 12.8 & 78.3 & 4.6 & 14.5 & $\mathbf{1 1 0 . 1}$ \\
Conventional tillage + bio-retting & 6.6 & 31.7 & 77.3 & 2.1 & $\mathbf{1 1 7 . 8}$ \\
\multicolumn{1}{|c}{ Yarn } & Cultivation & Agrochemicals & Retting & Textile processes & TOTAL \\
No till + water retting & 5.1 & 39.2 & 0.6 & 35.5 & $\mathbf{8 0 . 5}$ \\
Conservation tillage + stand/dew retting & 13.3 & 81.2 & 4.7 & 39.0 & $\mathbf{1 3 8 . 1}$ \\
Conventional tillage + bio-retting & 6.9 & 33.0 & 80.4 & 26.1 & $\mathbf{1 4 6 . 4}$ \\
\hline
\end{tabular}



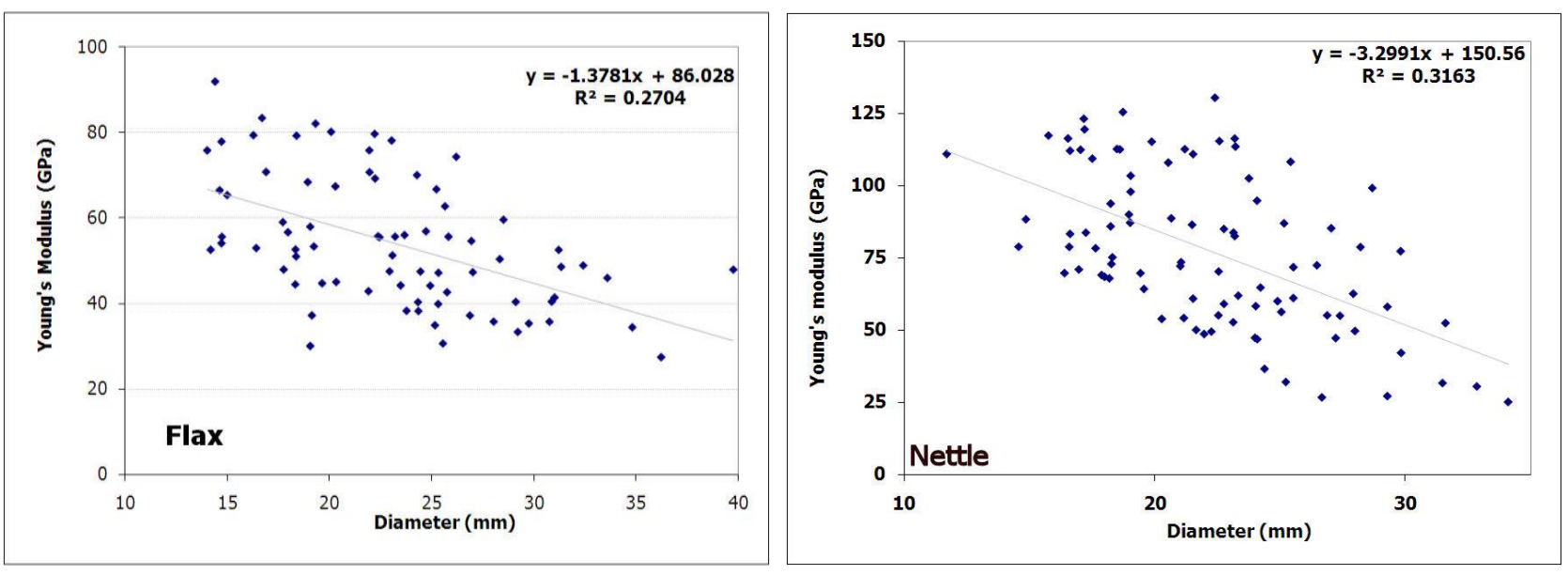

Figure 1: Young's modulus as a function of fibre diameter for (left) flax and (right) nettle (reproduced from data, published in [5] and [7] respectively, kindly provided by $\mathrm{C}$ Baley with permission for use here)

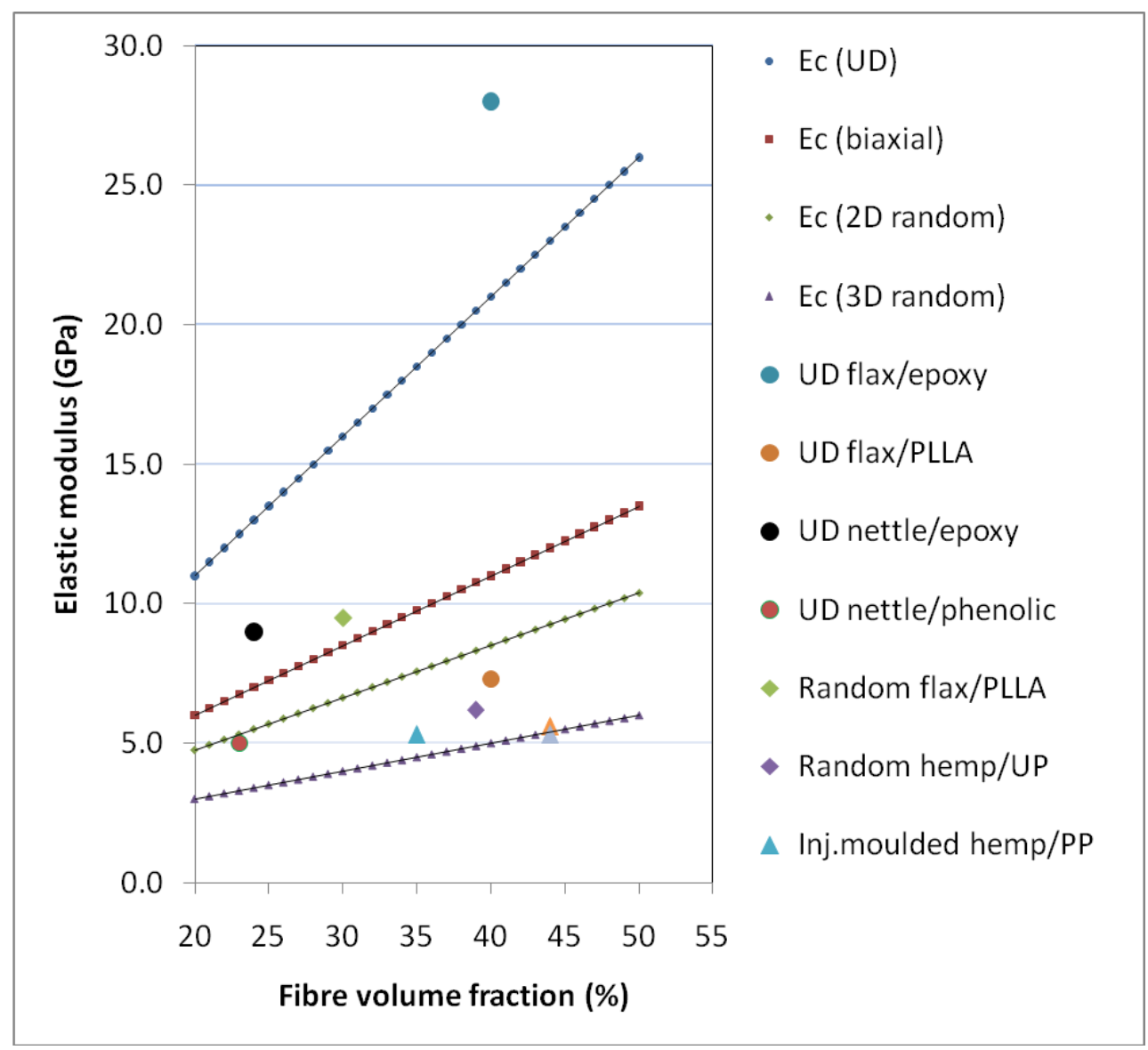

Figure 2: Variation of Young's modulus with fibre orientation plotted against fibre volume fraction (a constant fibre modulus of $50 \mathrm{GPa}$ has been assumed for the trendlines) 
Final manuscript of a paper published in Composites Part A:

Applied Science and Manufacturing 41,(10) 1336-1344, DOI: 10.1016/j.compositesa.2010.05.020
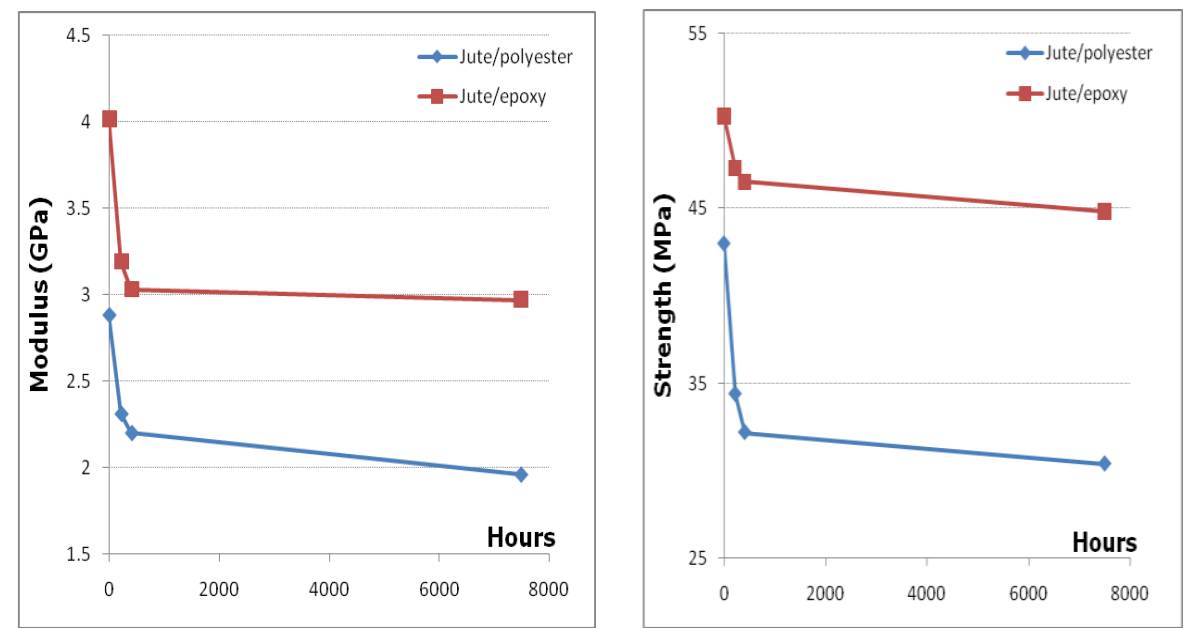

Figure 3: The deterioration of flexural modulus and strength for jute fibre composites exposed to distilled water for 0, 220, 410 or 7500 hours (data from Costa and D'Almeida [52])

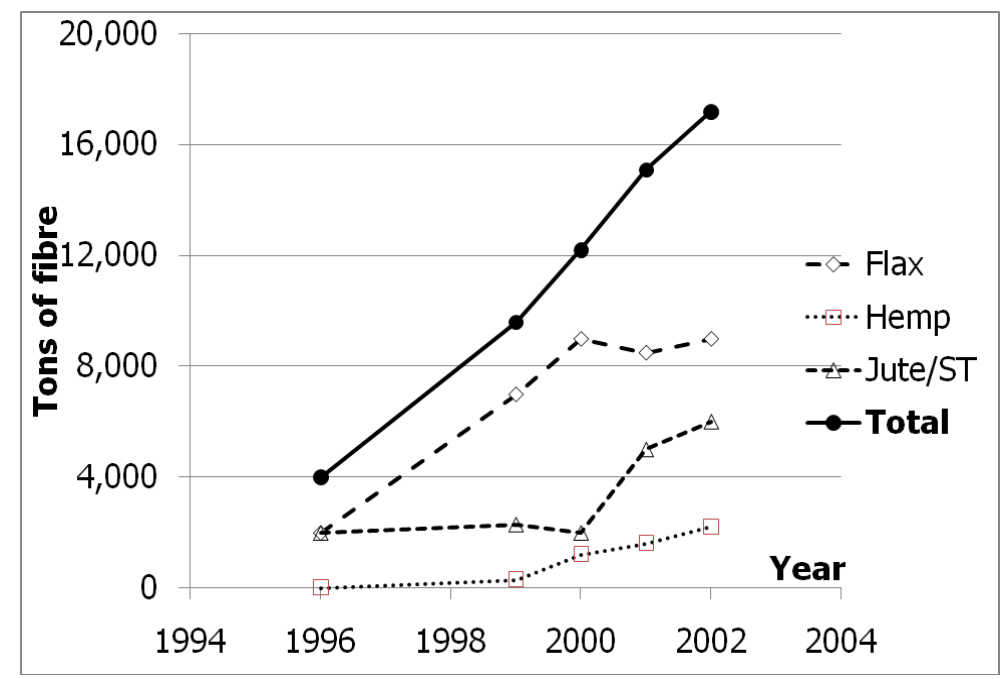

Figure 4: Use of natural fibres in the German automotive industry 1996 - 2002 (tonnes) (after Kaup et al [58]). 